\section{Invitation from Soviet centre}

\section{London}

PLANs to found an international research centre on Lake Baikal in south-east Siberia have been formally agreed in the Soviet Union, where the Soviet Academy of Sciences has deputed responsibility for the project to its Siberian Division. The division is now inviting putative members of the centre to declare their interest, and plans to hold a constitutional conference at Irkutsk in the second half of this year.

The formal announcement, contained in a cable to the Editor of Nature, is as follows: The Praesidium of the Siberian Division of the Academy of Sciences of the USSR announces its intention of organizing the Baikal Centre for Fundamental Ecological Research - an organization open for the collaboration of Soviet scientists and scientists of all other countries in studies of the greatest ancient freshwater lake, Lake Baikal.

The facilities of this centre are sited, and will be further developed, at Listvyanka, on the shore of Baikal, and in Irkutsk, $70 \mathrm{~km}$ away. The Limnological Institute at Irkutsk will provide research vessels (six ships), laboratory rooms, expeditions, equipment, hotel rooms, etc., as agreed with participating groups and contracted for.

It is proposed that the scientific prog-

\section{US UNIVERSITIES}

\section{MIT studies relations with Lincoln Laboratory Boston}

ThE Massachusetts Institute of Technology (MIT) has announced the formation of a committee to investigate the university's relationship with the federally sponsored Lincoln Laboratory in Lexington, Massachusetts. The laboratory's \$386-million annual budget is paid by the United States government, but the institute operates the facility.

At the core of the inquiry is the laboratory's emphasis on defence-related research involving radar and advanced electronics. Much of the work at the laboratory is classified, despite a university policy that eschews classified research on campus.

Paul Gray, president of MIT, says the new committee, headed by Joel Moses, chairman of MIT's electrical engineering and computer science department, will "explore alternative methods" for administering the Lincoln Laboratory. Gray has asked the committee to report by September. The group's twelve members also include Jerome B. Weisner, former president of MIT, Francis E. Low, former MIT provost, and Walker Morrow, Jr, director of Lincoln Laboratory. Seth Shulman ramme of the centre should include the following topics:

- Interdisciplinary studies of the Baikal ecosystem using the techniques of hydrodynamics, hydrochemistry, hydrobiology, remote sensing and mathematics in order to create a conceptual working model of this ecosystem.

- Studies of the speciation of the unique Baikal endemic complex of some 1,500 organisms and of the evolution of their nucleic acids and proteins.

- Investigation of the global transfer of elements and priority pollutants.

- The development of methods of environmental monitoring.

- Geological studies of Lake Baikal and of the history of its formation.

The Baikal International Centre will be operated by an international board of directors appointed by the founding parties. These will include the Siberian Division of the Academy of Sciences of the USSR, other Soviet organizations and organizations from other countries which agree to support the centre financially and to participate in its activities.

The board of directors will consider proposals for research projects and will select those to be carried out in each succeeding year on the basis of the reports of international referees. It will also decide what proportion of the budget will be devoted to each project selected in advance of each year's research.

Potential founding members of the Baikal International Centre - scientific institutes, scientific societies and international agencies - are hereby invited to open discussions with the Limnological Institute to clarify the framework of the agreement with the Siberian Division regarding participation in and support for the activity of the centre. Please write or cable to Professor M. A. Grachev, Lermontova 281, 664033 Irkutsk, USSR.

Inquirers will be supplied at their list of the scientists who have already endorsed the concept of the centre and who have participated in collaborative research at Baikal as well as with any other relevant information.

It is hoped to hold a conference with representatives of the founding members of the centre at Irkutsk in the second half of 1989

The cable is signed "Praesidium of the Siberian Division of the Academy of Sciences" and has been verified by telephone in a conversation with Professor Grachev. A general account of the Siberian Division's plans will be found in Nature 337 . 111; 12 January 1989.

- See page 209 of this issue for Professor Grachev's account of the canine distemper virus infection of Lake Baikal seals. request with a draft charter of the centre, a

\section{Third shuttle launch}

\section{Washington}

THE third space shuttle launch since flights resumed took place last Monday (13 March) when the shuttle Discovery lifted off from Cape Canaveral in Florida. The lift-off was delayed one hour and forty minutes by poor weather conditions at the launch site. The mission's primary goal is to deploy a third tracking and data relay satellite that will complete a system of communications satellites in geosynchronous orbit that facilitate much higher data rates from spacecraft to ground stations. The new system is essential to make optimal use of data from the Hubble Space Telescope to be launched in December. This telescope was costly and expectations of it are high (see page 199).

The next shuttle mission, scheduled for 28 April on the shuttle Atlantis, will launch the Magellan spacecraft, a planetary probe bound for Venus.

J.P.

\section{Blaser to retire from PSI}

Munich

J. P. BLASER will be retiring in the spring of 1990 as director of the Swiss Paul Scherrer Institute (PSI) for nuclear research in Villigen, near Zurich. The institute is currently seeking a replacement. Blaser, 66 , was formerly director at the Swiss Institute for Nuclear Research, which was fused with the Federal Institute for Reactor Research at the end of 1987 to form PSI.

S.D.

\section{New authority in view}

\section{London}

The task of reaching international consensus on how to combat global warming was tackled last week at an international conference on the environment held in the Hague, and organized by the governments of France, the Netherlands and Norway.

The declaration at the end of the conference calls for a new authority to be set up in the United Nations to be responsible for combating global warming. It says that the authority should undertake or commission scientific research and ensure the distribution of information between nations, including the sharing of technology. The authority would set standards for protection of the atmosphere and monitor compliance. But the conference decided not to endorse the imposition of economic sanctions on offending nations; measures to promote compliance would be referred to the International Court of Justice.

It was agreed, however, that developing countries should be compensated for any burden placed on them by the regulations, according to their responsibility for pollution. The organizers were criticized for their selective invitations - the United States and the Soviet Union were among those not invited. But the Dutch say all nations were invited to sign the declaration.

C.McG. 